\title{
BLOCKCHAIN AS A TECHNOLOGY ADMINISTRATION OF FAMILY HOMESTEAD SETTLEMENTS
}

Valentyna YAKOBCHUK, Zhytomyr National Agroecological University, blvd. Stariy, 7, 10008 Zhytomyr, Ukraine Mariia PLOTNIOVA, Zhytomyr National Agroecological University, blvd. Stariy, 7, 10008 Zhytomyr, Ukraine, mfplotnikova@gmail.com (corresponding author)

\begin{abstract}
Human community, whose behavior is determined by the influence of biological and social systems, the ability to realize and e valuate the results of its activities, orientation, strategic decisions, to ensure the sustainable development of the ecosystem, in a context of increasing the factor of limited resources (energy, materials, information) is transformed into intellectualization public relations and institutions. Rural development in the context of decentralization has led to the search for effective public administration mechanisms. The purpose of the study is to establish a mechanism for improving the territorial communities management technology on the example of Family Homesteads. The research methodology is based on structured interviews and unstructured conversations with the inhabitants of family homesteads, leadership of local self-government and experts in the field of rural development. Activation of the processes of rural development through the implementation of the idea of "Family Homestate" involves the participation of the population in the normative regulation (the adoption of the relevant law); assistance in the development of new settlements in rural areas by changing the status of the land, creating a land bank; activation of activity of public organizations registered in territorial communities, organization of settlements at the level of territorial communities, including the exchange of experience, coordination of activities in the middle of the movement, establishment of positive relations between the local population and immigrants and others like that. The advantages of the practice of public administration of the territory are established with the help of blockchain technology, which allows to reduce administration costs and promote resource participation.
\end{abstract}

Keywords: blockchain, family homesteads, family homestead settlement, public administration, rural communities, self-management, smart-community, social cohesion.

\section{INTRODUCTION}

Taking into account the asymmetries of local development and the need to increase the potential of the person and the ecosystem in general, the construction of interrelations and institutions between the community actors is due to the intensification of the communication process. The introduction of modern technologies in public administration and economic processes allows you to live comfortably, socially oriented and environmentally friendly. Focusing on the socialization of social processes, the development of the democratization of public administration, the strengthening of responsibility for their own lives and the surrounding space form qualitatively new standards of social life. We believe that rural inhabitants are most interacting with the natural environment, but they usually have a low experience of cooperation with authorities, formal social institutions, and less often than urban residents are involved in social activities that can successfully compensate for the introduction of block technologies in management processes. State management of rural development is a priority task that requires significant regulatory and legal regulation and participation of the society (the public is not socially active enough and needs social protection, which is $60 \%$ of Ukrainian society). The state policy in the field of sustainable development of rural areas envisages regulatory, socio-economic and administrative-organizational measures that are implemented by public management structures in order to increase the level and quality of life of the population.

Modern practice of rural development management requires wide access to new technologies. One of the most promising, according to the World Economic Forum (2017), is a technological block diagram that diversifies the decisionmaking system, increasing the efficiency of citizens' activities in the process of public administration, and provides the necessary motivation for participation in projects of local importance. Satoshi Nakomoto was created in 2008 as a mechanism for ensuring a high degree of reliability and identification of information, enabling it to be distributed on the networks, simultaneously working with several users, fixing the time of each operation. In fact, Blockchain is a system without a single center, which allows you to increase the degree of confidence in the information, leaving the identification of the record. The development of the blockchain of technologies lies in the interests of many domestic and foreign researchers, which distinguish its features such as the attraction and distribution of resources, transparency and confidentiality of information, promotion of the adoption of effective management decisions (Table 1).

The aim of this article is to analyze existing rural development problems and systematize mechanisms for their solution. The methodological basis of the study was the general and special methods of scientific knowledge. The research

Copyright (C) 2019 The Authors. Published by Vytautas Magnus University. This is an open-access article distributed under the terms of the Creative Commons Attribution License (CC-BY 4.0), which permits unrestricted use, distribution, and reproduction in any medium, provided the original author and source are credited. 
was conducted inductively through collecting and analyzing qualitative data and deductively through generalization of theoretical issues on the basis of systemic approach, which made possible to study synergetic transformations of nonlinear self-organized dynamic systems (society, economics, and ecology). Measurement of variables was carried out on the basis of sociological survey. During the years 2013-2017, 200 rural residents were examined (the average age of the respondents is 35 years) to identify socio-economic development factors of the communities. Selection for the purpose of the current study was based on a set of inclusion criteria 1) participants live in their own home or in family homestead at rural areas; 2) the yardstick utilized for this research are as follows: a) the size of the land plot is 1 ha, b) $0.3-0.5$ ha planted with perennial infertile trees; 3) the owners of the site use "green" technologies and are focused on ecological lifestyle. We used cluster sampling method for choosing human settlement. Location: Zhytomyr, Kirovohrad, Kyiv, Vinnytsia, Chernihiv, Sumy, Odessa and Kharkiv regions of Ukraine. Data collection: A structured undisguised questionnaire, which included close-ended questions on demographic profile and general information (10 questions), awareness on social capital and its functions (5 questions), was administered through a face to face in-depth interview. Ten statements (each to assess the respondents' attitude towards institutes that ought to be working at rural territories) were also prepared with. In addition, the effective implementation of the social institutes in the actual lifestyle premises by each respondent were recorded using an observation checklist (10 major guidelines). The general information of the participants with regards to the demographic data and type of food business is such: ninety four percentage of the study populace belong to early adulthood while only $6 \%$ belong to the late adulthood category. The gender ratio of the study populace revealed that forty-six percentage of participants in the study were men when compared to only 54\% of women participants. $80 \%$ of the respondents have a high school level education. Statistical, logical and regulatory methods are used to reveal the interconnection and interdependence between endogenous and exogenous factors in the development of rural areas and to substantiate proposals for amending the current legislation of Ukraine. The methods of comparative analysis and logical methods of research were used to analyze the data on the state and trends of the development of territorial communities.

Table 1. Characteristics of blockchain technology as an administrative decision-making system

\begin{tabular}{|c|c|c|c|c|c|c|c|c|c|c|c|c|}
\hline Authors & 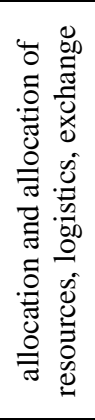 & 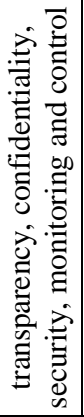 & 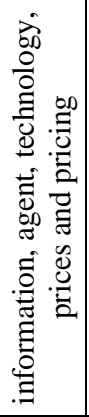 & 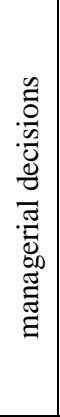 & 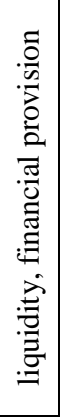 & 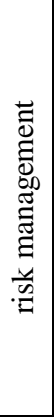 & 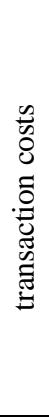 & 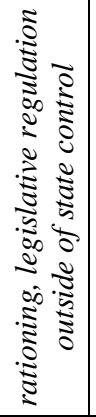 & 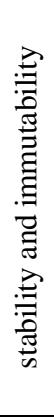 & 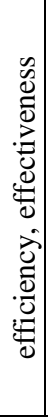 & 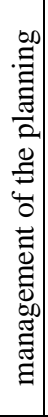 & 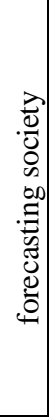 \\
\hline Pesch, U., Ishmaev, G. (Pesch, 2019) & & + & & & & & + & & & & & \\
\hline Van der Elst, C., Lafarre, A. (Van der Elst, 2019) & + & + & & + & + & & & + & + & & & \\
\hline Avgouleas, E., Kiayias, A. (Avgouleas, 2019) & & + & + & & & + & + & & + & & & \\
\hline Brownsword, R. (Brownsword, 2019) & + & & + & + & + & & & & & & + & \\
\hline $\begin{array}{l}\text { Fenwick, M., McCahery, J.A., Vermeulen, E.P.M. (Fenwick, } \\
\text { 2019) }\end{array}$ & + & + & & + & + & & & & & & + & + \\
\hline Pankowska, M. (Pankowska, 2019) & & + & + & + & & & + & & & & & \\
\hline Finck, M., Moscon, V. (Finck, 2019) & & & + & + & & & & + & & & & \\
\hline $\begin{array}{l}\text { Sobrinho, R.P., Garcia, J.R., Maia, A.G., Romeiro, A.R. } \\
\text { (Sobrinho, 2019) }\end{array}$ & + & & + & + & + & & & & & & & \\
\hline Pantykina, M. (Pantykina, 2019) & + & & & + & & + & & & & & + & \\
\hline Kim, M. S., Chung, J. Y. (Kim, 2018) & + & + & & & + & + & & + & & + & + & + \\
\hline Liao, D.-Y., Wang, X. (Liao, 2018) & + & + & + & + & & & + & & + & + & & \\
\hline Lee, J., Seo, A., Kim, Y., Jeong, J. (Lee, 2018) & + & + & & & & + & & & & + & & \\
\hline Ko, T., Lee, J., Ryu, D. (Ko, 2018) & + & + & & + & + & & + & & & + & & \\
\hline Yanovich, Y., Shiyanov, I.,Vorobyov, S. (Yanovich, 2018) & + & & + & & & + & & & & & & \\
\hline Yoo, M., Von, Y. (Yoo, 2018) & + & + & + & & & & + & & & & & \\
\hline Baranov, I. (Baranov, 2018) & + & + & & + & + & + & & + & + & & & \\
\hline Nikolakis, W., John, L., Krishnan, H. (Nikolakis, 2018) & & + & + & & & + & & + & + & & & \\
\hline Kouhizadeh, M., Sarkis, J. (Kouhizadeh, 2018) & + & & & & & & & & & & & \\
\hline Mao, D., Hao, Z., Wang, F., Li, H. (Mao, 2018) & + & + & + & & & & & & & + & & \\
\hline $\begin{array}{l}\text { The total number of positions noted by the authors } \\
\text { of the articles }\end{array}$ & 14 & 13 & 10 & 10 & 7 & 7 & 6 & 5 & 5 & 5 & 4 & 2 \\
\hline
\end{tabular}

The main resources of the article are best domestic practices and world experience, open results and data of the activities of international organizations, the State Statistics Committee of Ukraine, the Ministry of Agrarian Policy and Food of Ukraine. On this basis, to propose a set of measures aimed at overcoming existing asymmetries and disproportions. 


\section{THE CURRENT STATE OF DEVELOPMENT OF RURAL AREAS}

Modern trends in the development of society create the preconditions for the formation and application of the blockchain system. In particular, in this context, it is worthwhile to mention the advantages of the technology of the formation of intelligent communities. The tendency towards the organization of "reasonable" space: SMART-community, smart-technologies, smart-houses, smart-cities. Scheme for mapping the SMART community (Fig. 1).

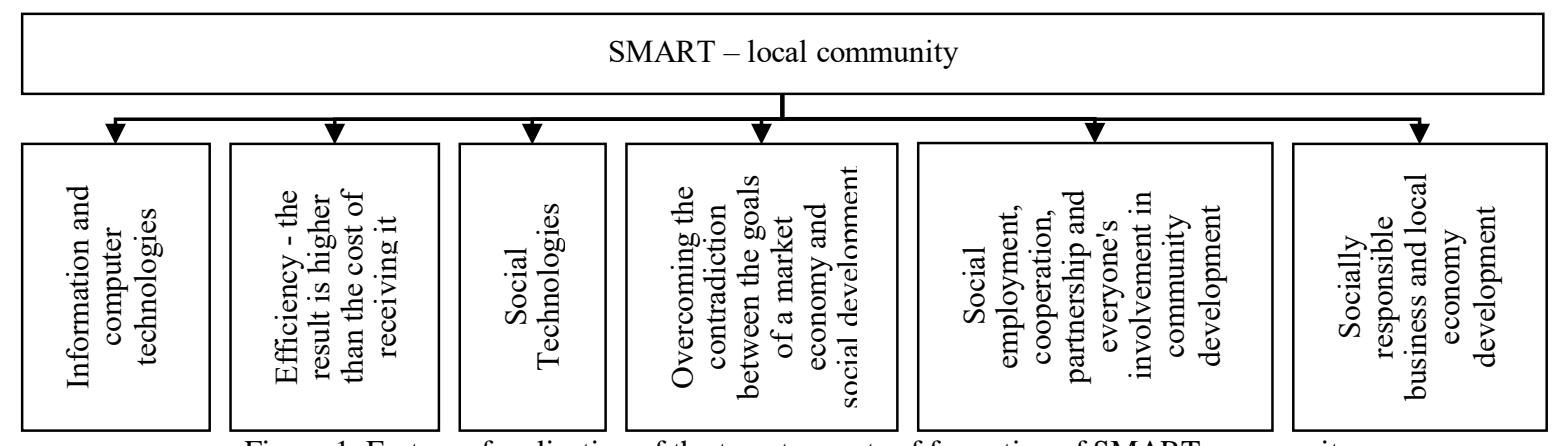

Figure 1. Factors of realization of the target aspects of formation of SMART-community.

At present, the two most common approaches to implementing "smart systems" are: 1) "from scratch" - it is noted by the best planning and implementation of advanced solutions, as well as the high cost of change, the gradual "aging" of technologies at the implementation stage; 2) modernization of existing systems using the existing economic and resource base, attracting investors and distributing risks, in particular through the participation of residents (the greater their number, the more extensive projects can be implemented - (Ermishina, 2016). The integration nature of projects, technologies, and communications makes it possible to obtain a synergistic effect from their joint implementation. As a rule, the main tasks of communities, which are solved, are safety of life, comfort in space, creation of a positive image. According to the research conducted, the processes of administration of community activity can be divided into two groups: main and providing. Under the main processes, we see the provision of public services to the inhabitants of the community with the maximum socio-economic-ecological effect. Under the ensuring - the processes of creating conditions for the realization of the goals of socio-economic and environmental development. The main ones, in turn, are divided into managerial (planning, organization and control of processes in the community) and public (in fact, the provision of services) (Table 2).

Table 2. Grouping the processes of the territorial community*

\begin{tabular}{|c|c|c|}
\hline $\begin{array}{c}\text { Groups of similar } \\
\text { processes }\end{array}$ & Processes of the territorial community & $\begin{array}{c}\text { Group } \\
\text { affiliation }\end{array}$ \\
\hline \begin{tabular}{|c|c|}
1. & \\
\end{tabular} & Study the needs of the community & $\mathrm{M}$ \\
\hline 2. & Analysis of the environment & $\mathrm{M}$ \\
\hline 3. & Strategic and operational planning & M \\
\hline 4. & Develop community strategy & $\mathrm{M}$ \\
\hline 5. & Socio-economic plan development of the community & $\mathrm{M}$ \\
\hline 6. & Marketing (creation of a positive image of the community) & $\mathrm{S}$ \\
\hline 7. & Diagnostics, monitoring & $\mathrm{S}$ \\
\hline 8. & Informational and consulting & $\mathrm{P}$ \\
\hline 9. & Public services development (identification of needs and means of satisfaction) & $\mathrm{P}$ \\
\hline 10. & Planning, organizing, motivating and controlling public services and processes in the community & $\mathrm{M}$ \\
\hline 11. & Rehabilitation of the potential and use of community resources & $\mathrm{S}$ \\
\hline 12. & Activation and activity of agents of change in the community & $\mathrm{S}$ \\
\hline 13. & Accounting and funding of community activities & $\mathrm{S}$ \\
\hline 14. & Institutional and infrastructural provision of community activity & $\mathrm{S}$ \\
\hline 15. & Introduction of creative technologies of community management & $\mathrm{M}$ \\
\hline 16. & Digitalization of processes (activities) of the community & $\mathrm{S}$ \\
\hline 17. & Human Resources Management & $\mathrm{M}$ \\
\hline 18. & External and internal communications & $\mathrm{S}$ \\
\hline 19. & Quality management of public services & $\mathrm{M}$ \\
\hline 20. & Quality management of community activity & $\mathrm{M}$ \\
\hline
\end{tabular}

* $\mathrm{M}$ - management processes; $\mathrm{P}$ - public activity; $\mathrm{S}$ - supporting and provision services.

The process of self-organization smart-community, digitalization of data on the resources of the territory contributes to the optimization of management decisions. Inventory monitoring as a basis for managerial decision-making and the components of administration have been reflected in numerous software tools. At the same time, such systems are not transparent enough for a large number of community residents. Blockchain technology allows you to use up-todate management information that is structured at the regional level and is accessible to central government and the local community, making it easy and quick to search 
The mechanism of public administration for the development of a territorial community using the technology of blockchain can be implemented for registration, accounting and transfer of all types of assets, including financial and land. At the same time, the number of participants and their geographical location does not matter, which changes the model of public administration qualitatively and allows for full decentralization of resources, the creation of a repository of large amounts of information. There are some blockchain systems in Estonia. It used for ensure full transparency of operations (from December 1, 2015). From 2016 in Sweden and Georgia blockchain used for land registration. From April 2017 in Georgia and Brazil it used for real estate register. Tatarstan uses blockchain for architectural affairs and providing bank guarantees.

The direct use of blockchain technology as a coherent rural governance system is in its infancy. Some elements of blockchain in software and social technology have been identified in Family Homestead Settlements as self-organized communities. These technologies are used locally (within one settlement or a whole community - a number of settlements) in order to improve the interaction of structural elements of local self-government bodies, as well as inform the population about management decisions both in the process of their adoption and from the standpoint of the resulting resolution. The introduction of blockchain technology made it possible for citizens to have free access to the system of support, adoption and control of power and management decisions

Innovative centers of consolidation formed within the territorial community are producers of new knowledge and technologies in the circle of like-minded people, when socialization and a friendly environment themselves are a system of production of social capital. Traditional cities are deprived of the opportunity to invest and innovate because of their spatial load (to place something new it is necessary to destroy what they have already placed), which clearly demonstrate projects Silicon Valley, Ile-de-France, designed outside of the metropolis (Antoun, 2004). An alternative approach to the organization and management of the development of territories is the development of self-organized communities. Based on national, global, human and socio-ecological principles, these newly formed communities as agents of change are active in the field of education and local self-government. As subjects of civil law, as individuals, and united in public organizations, cooperatives, associations, territorial communities and other forms of joint activity of citizens they express the interests of society in the places of residence. Their activity is based on the principles of sustainable social development (reasonable abundance - material production at the level necessary and sufficient for constant spiritual perfection), effective environmentally-friendly production (use of natural technologies, biomicricides in the social environment, organic production, permaculture design), self-management by the territory (public administration), noosphere approaches in the formation of worldview (noosphere education and upbringing). Developed by settlers economic relations are a real basis for reducing the level of import dependence of the country. Thanks to personal contact, there is a high level of horizontal interaction between the settlers which allows to expand the possibilities of joining labor, material and financial investments into the development of territories through the practice of intergroup and network interaction and public-private partnership. The share of settlers is the members of local self-government (deputies of village and district councils), which combine the problems of settlement and the region.

World experience shows that the issue of self-organization of the community, implemented in FHS. They are a space for the introduction of high-technology technologies and intensification of communications between all subjects of the territory. Mostly small settlements (on average up to 250 households), consisting of highly educated young people of childbearing age (the average age of settlers is 35 years old, $80 \%$ of which are higher education and active from the point of view of the demographic situation, investment activity and formation of the foundations of civil society, - the average family has 3 children, the contribution of each family over 10 years is more than 300 thousand UAH per 1 hectare area, many residents of the FH are members of local councils). Education in the field of IT and interest in technologies allows to develop public administration on the basis of blockchain technologies and implement the principles of direct democracy, absolute decentralization, including through computer technologies: the implementation of referenda on all issues of community development (organization of events, education systems, protection health and culture, scientific and research activities, local taxes, competitions, where everyone is a participant and judge, etc.). Each resident of the community is attached to the "Elections" system, which allows for the appropriate identification to vote for employment or dismissal of an appropriate specialist (in particular, the chairman of the council shall be removed from office if more than $75 \%$ of the voters voted for him, the judge is $50 \%$, district inspector $-25 \%$, etc.). In this way, community members feel and practice their own responsibility for it. Inclusive approaches to management and participation are provided by means of informatization, in particular by means of a mobile application or mobile device that can be delivered by a member of the community, to fix his opinion. It provides practically $100 \%$ of the residents' participation in community life (as opposed to $1-10 \%$ of citizens participating in community life in other territories). Residents of FH and FHS as the most active and responsible part of society actually realize this process both in real conditions and indirectly through the virtual environment. The consequence of decentralization was the transfer of powers and a significant part of fiscal charges on the ground, and an inclusive approach to governance contributes to preventing corruption. By spending about $3 \%$ of the budget of the community on the management system, other issues are decided on the joint efforts of all the participants.

The formation of modern communicative models in the conditions of the development of FHS contributes to the improvement of the information component of the public administration process. FHS as public organizations are a community of people living on the territory, united by a common infrastructure, operates on the basis of self-organization, based on common interests, values and traditions. They were created without additional stimulation from the state, they increased their number (in 2000 they were 2, in 2018 - 100 in 20 regions of Ukraine). in the northern and central parts of the country). The activities of the FH are widely represented in the Commonwealth of Independent States and a number of foreign countries, in particular, the Russian Federation (more than $80 \%$ of ecologically oriented settlements), Belarus 
(more than $90 \%$ of the representatives of environmental movements), Kazakhstan, Australia, Europe (in particular, Latvia, Lithuania, Czech Republic), North and South America and other countries. At the global level, the ideas of ecologization of life are promoted by the participants of the Global Ecovillage Network (GEN), at the regional level, they are residents of residents of FH and FHS.

The processes of decentralization that take place both in Ukraine and in the world as a whole are favorable conditions for the establishment of relevant institutions and platforms for the development of rural areas on qualitatively new grounds. Given that the average age of settlers is 35 years old, $80 \%$ of them have higher education (including $30 \%$ engineering), it is possible to implement science-intensive projects (this is evidenced by the experience of the ecological settlement of Tamerra in Portugal, which is the center of water treatment technologies and the development of renewable energy sources by virtue of the presence of Mars-2 project participants). At the same time, the main rate is placed on civil society institutions, in particular the activities of public organizations. Self-organization at the level of local communities is most fully and effectively implemented in FH and FHS, which are currently developing in the post-Soviet area and in a number of other countries.

\section{PERSPECTIVE DIRECTIONS OF DEVELOPMENT OF TERRITORIAL COMMUNITIES}

Family homestead as a new form of organization of society implements the interests of the community by creating conditions for improving the quality of life, the protection of nature and the rule of law through local and general selfgovernment (Sandal, 2019). These are manifested in ecological education, the organization of measures for environmental and people's local, national and international levels, the formation of social groups, the main of which are working groups (for the purpose of administering certain sectors of community development) and general meetings (Kavrakova, 2014) whose decisions There are at least $70 \%$ of their members at a joint meeting. Public administration in FHS is carried out in accordance with the principles of direct democracy through the mechanism of direct open voting at the time of making decisions, subject to the participation of every citizen in the administrative process (Fig. 2).

General meetings as a institute of civil society can capable of ensuring the self-organization of the population acts through general discussion and decision-making based on the integration of the interests of the inhabitants and consensus. The most effective method of its work is to establish a foresight method, in particular brainstorming, which allows finding the optimal solution, encouraging residents, teaching them to plan the future, optimizing the processes of adoption and implementation of decisions on the administration of community activity. As a form of public administration, selforganization of activities it is carried out through the activities of public organizations. In the presented organizational and communication structure, a system of public administration can be organically built on the basis of the introduction of block technologies, which will provide a number of integrated effects in the direction of sustainable development as a FHS, as well as rural territory as a whole. Taking into account the priority nature of the management of FHS - "without a single center", - effective organization and automation of administration processes are based on the implementation of the blockchain system.

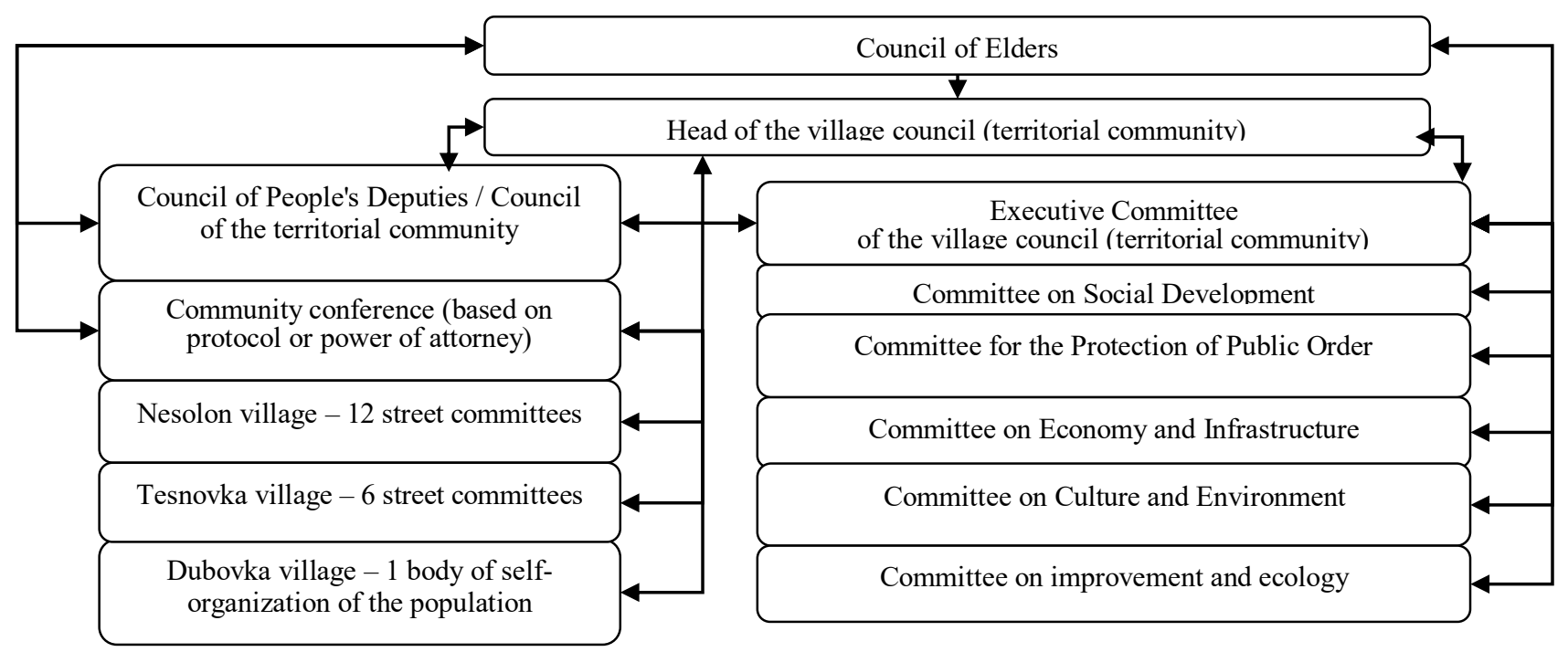

Figure 2. Organizational-communicative structure of the Nesolon territorial community

The use of blockchain in the process of making managerial decisions enables to ensure the preservation of all old solutions: from the promotion of the idea (using the individual key), all the processes of coordination (using the identification records), the introduction of all amendments, the fixing of interim and final results from all the issues considered. Changing even one letter, comma, or other character transforms the hash string into another. The function is irreversible. It allows you to consider all the stages of a management process, the history of its formation and the adoption of a resolution with the appropriate support of the organization of implementation of decisions. Recording technology itself complicates its distortion, which positively affects the position of transparency and accountability. Based on the trust of the participants in 
the process, the blockchain system accelerates the coordination processes of the participants and publicly highlights the outcome of the discussion. The public key of operations makes records accessible to all participants and reduces the impact of the main cause of crime - personal selfish interest. A practical example of the implementation of these approaches is carried out with the help of FH and FHS of Ukraine, when interaction between separate subjects is provided through the use of mobile devices and computers. The hash function, as a set of symbols, obtained mathematically, allows more open and effective management decisions, resource allocation and financial control. Several independent workstations of individual participants store information that makes it difficult for attackers to convert data. A transparent database of officials and other residents is open and allows them to record all the actions of the participants, in particular from the point of view of the cost of community resources and everyone is personally responsible for the consequences of their election. A small number of participants in the individual community allows you to know each other personally, and to use the blockchain to accelerate the adoption of managerial decisions, in particular between settlements within the country for the purpose of implementing joint projects. The system, being essentially blockchain and being implemented through the Internet, is not called in colloquial format. Due to its transparency, the system allows for the prevention of offenses.

An electronic system for the exchange of information between settlements allows solving the most important tasks, controversial issues are resolved through the voting mechanism (the decision is considered accepted, when it was supported by more than two thirds of the inhabitants) and the project management. At the same time, the main rate is placed on civil society institutions, in particular the activities of public organizations. Self-organization at the level of local communities is most fully and effectively implemented in FH and FHS, which are currently developing. Based on national, global, human and socio-ecological principles, these newly formed communities as agents of change are active in the field of education and local self-government. We give the idea about considering for the organization of production and provision of services in the form of Consumer Societies, which involve the production within the limits of the necessary for life, rather than profit, production processes and services within the same consumer society, can be expressed by the differential equation:

$$
\mathrm{H}=\left[\mathrm{y}^{1}(\mathrm{x})+\ldots+\mathrm{y}^{\mathrm{n}}(\mathrm{x})\right]=0
$$

де $\mathrm{x}$ - independent variable,

$\mathrm{y}(\mathrm{x})$ - function,

$\mathrm{y}^{1}(\mathrm{x}), \ldots, \mathrm{y}^{\mathrm{n}}(\mathrm{x})-$ derivatives,

$\mathrm{H}$ - total result of the equation (income).

The formula gives the understanding that the ideal organization of industrial relations in a consumer society generates zero income. This is due to the commitment of the members of the company to better meet the needs of the founders, rather than to profit or profit through cooperation with intermediary bodies, such as banks.

\section{CONCLUSIONS}

The experience of foreign ecological settlements and domestic clan settlements testifies that the level of education and qualification of modern migrants from cities to rural territories allows the development of a knowledge-intensive sector, in particular from the point of view of ecologization and management, the dissemination of best practices in water and air reclamation, soil fertility, use of renewable sources of energy, implementation of waste-free life and natural processes in the life of society. The collective type of community organization and the widespread involvement of information technology in the Republic of Poland allows to enhance the prospects of investment activity in the territory, to form the socio-psychological environment of like-minded people with shared values and positive-constructive ecological projects that are hereditary (passed on to children).

The conducted studies prove the expediency of using the blockchain system in the public management and administration of Family Homestead Settlements. The intensification of the processes of public management of FHS on the basis of fundamentally new technologies will facilitate the coordination of rural development with the implementation of the idea of the "Family homestead", simplify and make accessible, using the network and information systems, participation of the population in resolving issues of normative regulation of the development of FH and FHS (adoption of the relevant law); will promote the development of new settlements in rural areas by changing the status of the land, creating a bank of land; activization of activity of public organizations registered in territorial communities. Conducting informational and explanatory work on the essence of the idea of "Family Homestead" on the basis of blockchain technologies, organization of smart settlements at the level of territorial communities, including the exchange of experience, coordination of activities in the middle of the movement, establishment of positive relations between the local population and settlers, priority tasks a new model of public administration for the development of rural areas.

\section{REFERENCES}

1. Pesch U., Ishmaev G. 2019. Fictions and Frictions: Promises, Transaction Costs and the Innovation of Network Technologies. Social Studies of Science, Vol. 49(2), pp. 264-277 https://doi.org/10.1177/0306312719838339

2. Van der Elst C., Lafarre A. 2019. Blockchain and Smart Contracting for the Shareholder Community. Journal of European Business Organization Law Review, Vol. 20(1), pp. 111-137 https://doi.org/10.1007/s40804-019-00136-0 
3. Avgouleas E., Kiayias A. 2019. The Promise of Blockchain Technology for Global Securities and Derivatives Markets: The New Financial Ecosystem and the "Holy Grail" of Systemic Risk Containment. European Business Organization Law Review, Vol. 20(1), pp. 81-110. https://doi.org/10.1007/s40804-019-00133-3

4. Brownsword R. 2019. Regulatory Fitness: Fintech, Funny Money, and Smart Contracts. European Business Organization Law Review. 20(1), 5-27 https://doi.org/10.1007/s40804-019-00134-2

5. Fenwick M., McCahery J. A., Vermeulen E. P. M. 2019. European Business Organization Law Review The End of 'Corporate' Governance: Hello 'Platform' Governance. European Business Organization Law Review, Vol. 20(1), pp. 171-199. https://doi.org/10.1007/s40804-019-00137-z

6. Pankowska M. 2019. Information technology outsourcing chain: Literature review and implications for the development of distributed coordination. Sustainability, Vol. 11 (5), ID 1460 https://doi.org/10.3390/su11051460

7. Finck M., Moscon V. 2019. Copyright Law on Blockchains: Between New Forms of Rights Administration and Digital Rights Management 2.0: IIC International Review of Intellectual Property and Competition Law, Vol. 50(1), pp. 77-108 https://doi.org/10.1007/s40319-018-00776-8

8. Sobrinho R. P., Garcia J. R., Maia A. G.. Romeiro A. R. 2019. Tecnologia blockchain: Inovação em pagamentos por serviço ambientais. Estudos Avancados, Vol. 33(95), pp. 151-175. https://doi.org/10.1590/s0103-4014.2019.3395.0010

9. Pantykina M. 2019. Blockchain and social concepts: Exposure of the problem field. Sotsiologicheskoe Obozrenie, Vol. 18(1), pp. 158-185. https://doi.org/10.17323/1728-192x-2019-1-158-185

10. Kim M. S., Chung J. Y. 2018. Sustainable growth and Token economy design: Case of Steemit. Sustainability, Vol. 11(1), ID 167. https://doi.org/10.3390/su11010167

11. Liao D.-Y., Wang X. 2018. Applications of blockchain technology to logistics management in integrated casinos and entertainment. Informatics, Vol. 5(4), 44. https://doi.org/10.3390/informatics5040044

12. Lee J., Seo A., Kim Y., Jeong J. 2018. A blockchain-based one-off address system to ensure transparency and privacy for a sustainable donation environment. Sustainability, Vol. 10 (12), ID 4422. https://doi.org/10.3390/su10124422

13. Ko T., Lee J., Ryu D. 2018. Blockchain technology and manufacturing industry: Real-time transparency and cost savings. Sustainability, Vol. 10 (11), ID 4274. https://doi.org/10.3390/su10114274

14. Yanovich Y., Shiyanov I., Myaldzin T., Korepanova D., Vorobyov S. 2018. Blockchain-based supply chain for postage stamps. Informatics, Vol. 5(4), 42. https://doi.org/10.3390/informatics5040042

15. Yoo M., Won Y. 2018. A study on the transparent price tracing system in supply chain management based on blockchain. Sustainability, Vol. 10(11), ID 4037. https://doi.org/10.3390/su10114037

16. Tallyn E., Pschetz L., Gianni R., Speed C., Elsden C. 2018. Exploring machine autonomy and provenance data in coffee consumption: A field study of bitbarista. Proceedings of the ACM on Human-Computer Interaction, Vol. 170. https://doi.org/10.1145/3274439

17. Baranov, I. (2018) Creation of trust in the Russian cryptocurrency market. J. Ekonomicheskaya Sotsiologiya. 19(5), 90-112. https://doi.org/10.17323/1726-3247-2018-5-90-112

18. Nikolakis W., John L., Krishnan,H. 2018. How blockchain can shape sustainable global value chains: An Evidence, Verifiability, and Enforceability (EVE) Framework. Sustainability, Vol. 10(11), ID 3926. https://doi.org/10.3390/su10113926

19. Kouhizadeh M., Sarkis J. 2018. Blockchain practices, potentials, and perspectives in greening supply chains. Sustainability, Vol. 10(10), ID 3652. https://doi.org/10.3390/su10103652

20. Mao D., Hao Z., Wang,F., Li H. 2018. Innovative blockchain-based approach for sustainable and credible environment in food trade: A case study in Shandong Province, China. Sustainability, Vol. 10(9), ID 3149. https://doi.org/10.3390/su10093149

21. Ermishina A. V., Klimenko L. V. (eds.) 2016. Search masturbationsex patterns of living arrangement. In: Rostov-on-don, Science and Education Foundation.

22. Antoun L. L. 2004. International competitiveness of countries: theory of the mechanism of implementation. Kyiv, KNEU.

23. Kavrakova E. V. 2014. The Chamber as a form of democracy among the Slavs: history and modernity. Actual problems of Russian law, Vol. 12, pp. 2690-2694. 